\title{
PENGARUH LAMA PENYINARAN TERHADAP PERTUMBUHAN DAN KLOROFIL a Gracilaria verrucosa PADA SISTEM BUDIDAYA INDOOR \\ THE INFLUENCE OF RADIATION TIME OF GROWTH AND CHLOROPHYLL a Gracilaria verrucosa IN INDOOR CULTIVATION SYSTEM
}

\author{
Moch. Amin Alamsjah, Nurines Oktavia Ayuningtiaz dan Sri Subekti \\ Fakultas Perikanan dan Kelautan Universitas Airlangga \\ Kampus C Mulyorejo - Surabaya, 60115 Telp. 031-5911451
}

\begin{abstract}
Gracilaria cultivation is basically in need of lighting for photosynthesis process which will be a great effect on growth. The use of fluorescent (FL) as a replacement for the sun light is used for fluorescent lamps produce white light, except that fluorescent lights do not increase the room temperature drastically culture (temperature stable) and the intensity of light produced in the culture room suitable for the growth of shoots Gracilaria verrucosa. In addition to light intensity, while irradiation also affects the growth of cultured algae. Long exposures are generally set according to the needs of algae in natural conditions. In the process of photosynthesis is need a light and dark reaction. Light reaction occurs in the conversion of light energy into chemical energy and dark reactions occur for the formation of glucose that used for catabolism system.

This study aims to determine the best long exposures of the different long exposures which can affect the growth and the amount of chlorophyll a of $G$. verrucosa. The methods is an experimental that used Complete Random Design (RAL) as the experimental design. The treatment used is different irradiation time, the treatment A (long irradiation for 24 hours, control), treatment B (irradiation time 12 hours light: 12 hours dark), treatment C (irradiation time 8 hours light: 16 hours dark) and D treatment (irradiation time 16 hours light: 8 hours dark) of each treatment is repeated five times. The main parameters were observed daily growth rate (\%/day) and the amount of chlorophyll $a$ $(\mu \mathrm{g} / \mathrm{ml})$ of $G$. verrucosa. Supporting the observed parameters are $\mathrm{pH}$, temperature $\left({ }^{\circ} \mathrm{C}\right)$ and salinity $(\% \mathrm{o})$ The analysis data is using of variants analysis (ANOVA), if there is a difference data followed by Duncan's Multiple Range Test to determine the best treatment.

The results showed that different irradiation time take a real effect $(\mathrm{P}<0.05)$ on the growth and the amount of chlorophyll $a$ G. verrucosa. Daily weight growth rate of the highest average found in treatment $\mathrm{D}$ (irradiation time 16hour light: 8-hours dark) of $0.62 \% /$ day, and the lowest in treatment A (24-hour long light irradiation) of $0.23 \% /$ day. The highest number of chlorophyll a average at the end of the study are in treatment $\mathrm{D}$ (irradiation time 16-hours light: 8 hours dark) of $0.0068 \mu \mathrm{g} / \mathrm{ml}$ and the lowest in treatment A (24-hour long light irradiation) of $0.0048 \mu \mathrm{g} / \mathrm{ml}$. The increasing daily growth rate of $G$. verrucosa can used of the irradiation time 16-hours light: 8-hours dark.
\end{abstract}

Key words : radiation time, chlorophyll $a$, Gracilaria verrucosa

Pendahuluan

Rumput laut (seaweed) yang dalam dunia ilmu pengetahuan dikenal sebagai Algae sangat populer dalam dunia perdagangan akhir-akhir ini. Rumput laut dikenal pertama kali oleh bangsa Cina kira-kira tahun 2700 SM. Pada saat itu rumput laut banyak digunakan untuk sayuran dan obat-obatan. Pada tahun 65 SM, bangsa Romawi memanfaatkannya sebagai bahan baku kosmetik. Namun dengan perkembangan waktu, pengetahuan tentang rumput laut pun semakin berkembang.
Makroalga atau rumput laut merupakan salah satu sumberdaya laut yang sangat potensial (Atmadja, 1996). Terdapat sekitar 18.000 jenis rumput laut di seluruh dunia dan 25 jenis diantaranya memiliki nilai ekonomi tinggi. Indonesia terdapat 555 jenis rumput laut dan empat jenis diantaranya dikenal sebagai komoditas ekspor, yaitu Euchema sp., Gracilaria sp., Gelidium sp. dan Sargasum sp. Rumput laut atau yang biasa disebut dengan seaweed merupakan tanaman makro alga yang hidup di laut yang tidak memiliki akar, batang dan daun sejati dan pada umumnya hidup di dasar perairan. Rumput laut disebut tanaman karena memiliki klorofil (zat hijau daun) sehingga bisa 
berfotosintesis. Rumput laut juga sering disebut sebagai alga atau ganggang pada daerah tertentu di Indonesia.

Rumput laut yang banyak dimanfaatkan adalah dari jenis ganggang merah (Rhodophyceae) karena mengandung agar-agar, karaginan, porpiran, furcelaran maupun pigmen fikobilin yang terdiri dari fikoeretrin dan fikosianin yang merupakan cadangan makanan yang mengandung banyak karbohidrat. Tetapi ada juga yang memanfaatkan jenis ganggang coklat (Phaeophyceae). Saat ini penggunaan agar-agar semakin berkembang, yang dulunya hanya untuk makanan saja sekarang telah digunakan dalam industri tekstil, kosmetik, dan lain-lain. Fungsi utamanya adalah sebagai bahan pemantap, dan pembuat emulsi, bahan pengental, bahan pengisi, dan bahan pembuat gel. Dalam industri, agar-agar banyak digunakan dalam industri makanan seperti untuk pembuatan roti, sup, saus, es krim, jelly, permen, serbat, keju, puding, selai, bir, anggur, kopi, dan cokelat. Dalam industri farmasi bermanfaat sebagai obat pencahar atau peluntur, pembungkus kapsul, dan bahan campuran pencetak contoh gigi. Dalam industri tekstil dapat digunakan untuk melindungi kemilau sutera. Dalam industri kosmetik, agar-agar bermanfaat dalam pembuatan salep, krem, lotion, lipstik, dan sabun. Selain itu masih banyak manfaat lain dari agar-agar, seperti untuk pembuatan pelat film, pasta gigi, semir sepatu, kertas, dan pengalengan ikan dan daging. Karaginan merupakan senyawa polisakarida yang tersusun dari unit D-galaktosa dan L-galaktosa 3,6 anhidrogalaktosa yang dihubungkan oleh ikatan 1-4 glikosilik. Kegunaan karaginan hampir sama dengan agar-agar, antara lain sebagai pengatur keseimbangan, pengental, pembentuk gel, dan pengemulsi. Algin ini didapatkan dari rumput laut jenis algae coklat. Kegunaan algin dalam industri ialah sebagai bahan pengental, pengatur keseimbangan, pengemulsi, dan pembentuk lapisan tipis yang tahan terhadap minyak.

Hoyle (1973) dalam Atmadja dkk. (1996) menyatakan bahwa rumput laut Gracilaria sp. merupakan tumbuhan yang mempunyai toleransi terhadap perubahan kondisi lingkungan serta dapat tumbuh pada perairan yang tenang. Chen dan Shang (1980) dalam Atmadja dkk. (1996) menyatakan bahwa rumput laut Gracilaria sp. di tambak berhasil dibudidayakan sejak tahun 1962 di Taiwan yang terdiri dari limajenis, yaitu Gracilaria confervoides, G. gigas, G. chorda, G. lichenoides dan $G$. compressa.

Sulistjo dan Atmadja (1993) dalam Atmadja dkk. (1996) menyatakan bahwa perkembangan budidaya rumput laut Gracilaria sp. di tambak wilayah Indonesia terdapat di daerah Sulawesi Selatan, Jawa Timur dan Nusa Tenggara Barat. Jenis yang dibudidayakan adalah Gracilaria gigas, G. verrucosa dan G. lichenoides. Salah satu jenis alga merah yang banyak ditemukan di perairan Indonesia adalah $G$. verrucosa dan merupakan penghasil agar (Lewmanomont, 1995). Produksi rumput laut $G$. verrucosa dari tambak dapat mencapai minimal 1 ton kering ha/periode tanam (4 - 6 minggu). Pada musim hujan pertumbuhan rumput laut $G$. verrucosa lambat, sehingga tidak dapat berproduksi dan hanya dipelihara untuk persediaan bibit. Hal ini disebabkan karena perubahan suhu dan salinitas air laut yang mengalami penurunan sehingga tidak dapat memenuhi kriteria suhu dan salinitas yang diharapkan untuk pertumbuhan rumput laut.

Rumput laut merupakan salah satu komoditas perikanan yang diandalkan dalam program revitalisasi perikanan. Sebagai bahan dasar penghasil agar, alginate dan karaginan rumput laut sangat laku di pasaran baik dalam negeri maupun ekspor. Menurut Mukhtar (2008) pada 2007 produksi rumput laut Indonesia mencapai 94 ribu ton. Pada akhir tahun 2008, pemasokan rumput laut terhadap permintaan pasar di Indonesia masih sangat kurang, yaitu hanya berkisar 13,1\%. Rendahnya pasokan tersebut disebabkan karena kegiatan budidaya yang kurang baik dan kurangnya informasi tentang potensi rumput laut kepada para petani.

Kualitas rumput laut sangat ditentukan oleh kandungan agar yang merupakan produk dari hasil fotosintesis rumput laut. Semakin tinggi nilai kandungan agar, maka semakin baik kualitas rumput laut. Salah satu cara untuk meningkatan laju fotosintesis pada rumput laut yaitu dengan memanipulasi lama penyinaran terhadap pertumbuhannya. Pada lama penyinaran optimum rumput laut diharapkan akan menghasilkan produk fotosintesa yang maksimal. Hambatan lain yang terjadi pada perkembangan rumput laut di Indonesia ini adalah kualitas rumput laut yang kurang baik, khususnya pada produksi agarnya sehingga masih perlu dioptimalkan teknik budidaya rumput laut $G$. verrucosa secara indoor dengan cara manipulasi penyinaran. Cahaya mempunyai peranan yang sangat penting terhadap proses fotosintesis yang mempengaruhi intensitas dan panjang gelombang (Sudiaji, 2005). Pada penelitian ini diharapkan adanya lama penyinaran terbaik yang dapat mempengaruhi proses pertumbuhan dan jumlah klorofil $a$ dari $G$. verrucosa. 
Penelitian ini bertujuan untuk mengetahui lama penyinaran yang dapat mempengaruhi pertumbuhan $G$. verrucosa pada sistem budidaya secara indoor. Selain itu juga untuk mengetahui lama penyinaran yang dapat mempengaruhi jumlah klorofil $a$ pada $G$. verrucosa pada sistem budidaya secara indoor.

\section{Materi dan Metode Penelitian}

Tempat dan Waktu

Penelitian ini akan dilaksanakan pada 19 Juni - 3 Agustus 2009 di Laboratorium kering Fakultas Perikanan dan Kelautan Universitas Airlangga Surabaya dan tambak budidaya rumput laut di Desa Pulokerto, Kecamatan Kraton, Kabupaten Pasuruan.

\section{Alat Penelitian}

Peralatan yang digunakan dalam penelitian ini adalah 20 buah wadah dengan volume 1,5 liter, tandon air laut, selang aerasi, batu aerator, lampu fluorescent 40 watt, plastik atau mulsa hitam, aerator, tali, tabung reaksi, mikropipet, timbangan digital, refraktometer, termometer, $\mathrm{pH}$ indikator universal dan spektrofotometer.

\section{Bahan Penelitian}

$G$. verrucosa yang digunakan adalah G.verrucosa pada bagian thallus muda dengan panjang $5 \mathrm{~cm}$. Thallus muda berwarna kuning kehijauan. $G$. verrucosa berasal dari tambak budidaya rumput laut di Desa Pulokerto, Kecamatan Kraton, Kabupaten Pasuruan.

Media yang digunakan dalam penelitian ini adalah air laut sebanyak 1 liter. Air laut berasal dari perairan Tanjung Perak Surabaya, dengan kedalaman $10 \mathrm{~m}$ dari dasar laut. Salinitas air laut media adalah 30 permil. Media penelitian dijaga tetap optimum dan setiap tiga hari sekali dilakukan pergantian air Villares et al.(1999). Pergantian air sebanyak 100\% dengan air laut baru, caranya dengan menyifon bagian yang kotor kemudian menggantinya dengan air laut bersih.

Pupuk NPK yang digunakan dalam penelitian ini adalah pupuk NPK Phonska yang diproduksi oleh PT. Petrokimia Gresik, terdiri dari unsur nitrogen $(\mathrm{N}) 15 \%$, fosfat $\left(\mathrm{P}_{2} \mathrm{O}_{5}\right) 15 \%$, kalium $\left(\mathrm{K}_{2} \mathrm{O}\right) 15 \%$ dan sulfur (S) $10 \%$. Pupuk TSP yang digunakan dalam penelitian ini adalah SP-36 Petrokimia Gresik yang diproduksi oleh PT. Gresik Cipta Sejahtera yang mengandung fosfat $\left(\mathrm{P}_{2} \mathrm{O}_{5}\right) 18 \%$.

\section{Metode Penelitian}

Metode penelitian yang digunakan dalam penelitian ini adalah metode eksperimental. Penelitian eksperimental pada dasarnya adalah ingin menguji hubungan antara suatu sebab dengan akibat. Penelitian ini bertujuan untuk mengetahui kemungkinan hubungan sebab akibat dengan cara memberikan satu atau lebih perlakuan pada satu atau lebih penelitian dan membandingkannya dengan kontrol yang tidak diberikan perlakuan (Silalahi, 2003).

\section{Hasil dan Pembahasan}

Hasil penelitian pengaruh lama penyinaran terhadap pertambahan berat rumput laut $G$. verrucosa, yang ditimbang setiap 7 hari sekali selama 5 minggu dapat dilihat pada Lampiran 1. Data tersebut digunakan untuk menghitung laju pertumbuhan berat harian (DGR) yang disajikan pada Lampiran 2. Data yang didapatkan dari pengukuran tersebut digunakan untuk mengetahui pengaruh lama penyinaran terhadap pertumbuhan $G$. verrucosa. Hasil pengukuran pertambahan berat rata-rata $G$. verrucosa pada penyinaran yang berbeda yang dilakukan setiap minggu selama penelitian dapat dilihat pada Gambar 1 .

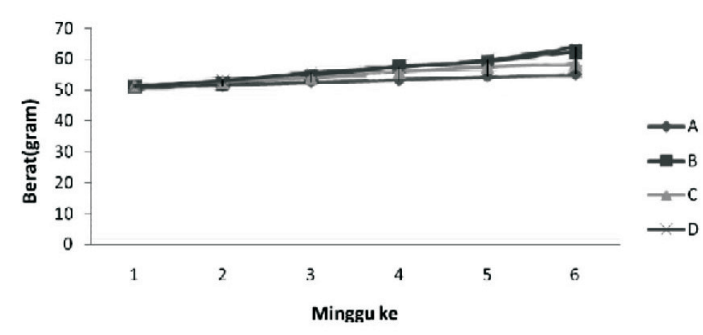

Gambar 1. Grafik pertambahan berat G. verrucosa pada lama penyinaran yang berbeda

Keterangan: A(Kontrol, 24 jam terang)

B (Lama penyinaran 12 jam terang:12 jam gelap)

C (Lama penyinaran 8 jam terang:16 jam gelap)

D (Lama penyinaran 16 jam terang:8 jam gelap)

Hasil penghitungan Anova laju pertumbuhan berat harian $G$. verrucosa menunjukkan adanya pengaruh dari lama penyinaran terhadap laju pertumbuhan berat harian G. verrucosa $(\mathrm{p}<0,05)$. Hasil tersebut dilanjutkan dengan uji jarak berganda Duncan yang menunjukkan bahwa lama penyinaran yang dapat memberikan laju pertumbuhan berat harian G. verrucosa terbaik adalah perlakuan D (lama 
penyinaran 16 jam terang : 8 jam gelap) yang tidak berbeda nyata $(p>0,05)$ dengan perlakuan B (lama penyinaran 12 jam terang : 12 jam gelap), dan perlakuan D (lama penyinaran 16 jam terang : 8 jam gelap) berbeda nyata $(\mathrm{p}<0,05)$ dengan perlakuan $\mathrm{C}$ (lama penyinaran 8 jam terang : 16 jam gelap) dan perlakuan A (kontrol, 24 jam penyinaran). Hasil uji jarak Duncan terhadap pertumbuhan berat rata-rata $G$. verrucosa pada setiap perlakuan terdapat pada Tabel 1.

Tabel 1. Hasil uji jarak Duncan terhadap pertumbuhan berat rata-rata $G$. verucossa

\begin{tabular}{|c|c|}
\hline Perlakuan & $\begin{array}{c}\text { Laju pertumbuhan } \\
\text { berat rata-rata (\%) }\end{array}$ \\
\hline $\begin{array}{c}\text { A (Kontrol, 24 jam } \\
\text { penyinaran) }\end{array}$ & $0.23^{\mathrm{c}}$ \\
B (Lama penyinaran 12 \\
jam terang : 12 jam gelap) \\
$\begin{array}{c}\text { C (Lama penyinaran 8 } \\
\text { jam terang : 16 jam gelap) }\end{array}$ & $0,57^{\mathrm{a}}$ \\
$\begin{array}{c}\text { D (Lama penyinaran 16 } \\
\text { jam terang : 8 jam gelap) }\end{array}$ & $0,38^{\mathrm{b}}$ \\
\hline
\end{tabular}

Keterangan: Superskrip yang berbeda menujukkan perbedaan $(\mathrm{p}<0,05)$

Penghitungan Anova dan uji jarak berganda Duncan laju pertumbuhan berat harian. Laju pertumbuhan berat harian rata-rata $G$. verrucosa pada akhir penelitian adalah perlakuan A $(0,23 \% /$ hari $)$, perlakuan B $(0,57 \% /$ hari $)$, perlakuan $\mathrm{C}(0,38 \% /$ hari $)$, dan perlakuan $\mathrm{D}(0,62 \%$ /hari $)$.

Hasil penelitian pengaruh lama penyinaran terhadap jumlah klorofil a rumput laut G. verrucosa, yang diukur pada minggu pertama dan minggu terakhir selama 5 minggu penelitian. Data tersebut digunakan untuk menghitung jumlah klorofil a G. verrucosa. Data yang didapatkan dari pengukuran tersebut digunakan untuk mengetahui pengaruh lama penyinaran terhadap jumlah klorofil $a$ G. verrucosa. Hasil pengukuran jumlah klorofil $a$ G. verrucosa pada penyinaran yang berbeda yang dilakukan pada awal minggu pertama dan minggu terakhir selama penelitian dapat dilihat pada Gambar 2 .

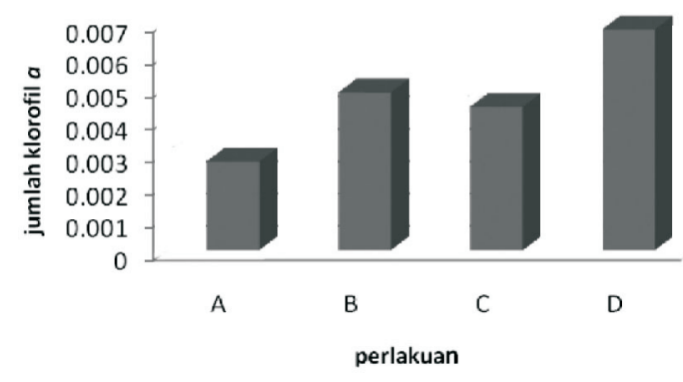

Gambar 2. Grafik pertambahan jumlah klorofil $a G$. verrucosa
Keterangan: A(Kontrol, 24 jam terang)
B (Lama penyinaran 12 jam terang:12 jam gelap)
C (Lama penyinaran 8 jam terang:16 jam gelap)
D (Lama penyinaran 16 jam terang:8 jam gelap)

Hasil penghitungan Anova menunjukkan bahwa lama penyinaran pada $G$. verrucosa berpengaruh nyata $(\mathrm{p}<0,05)$ terhadap jumlah klorofil $a$ G. verrucosa. Hasil tersebut dilanjutkan dengan uji jarak berganda Duncan, yang menunjukkan bahwa pengaruh lama penyinaran yang dapat memberikan jumlah klorofil $a$ terbaik adalah perlakuan D (lama penyinaran 16 jam terang : 8 jam gelap) yang berbeda nyata $(\mathrm{p}<0,05)$ dengan perlakuan $B$ (lama penyinaran 12 jam terang : 12 jam gelap) dan perlakuan B (lama penyinaran 12 jam terang : 12 jam gelap) yang tidak berbeda nyata $(\mathrm{p}>0,05)$ dengan perlakuan $\mathrm{C}$ (lama penyinaran 8 jam terang : 16 jam gelap). Hasil terendah diperoleh perlakuan A (kontrol, 24 jam penyinaran) yang berbeda nyata $(\mathrm{p}<0,05)$ dengan perlakuan $\mathrm{C}$ (lama penyinaran 8 jam terang : 16 jam gelap). Penghitungan Anova dan uji jarak berganda Duncan jumlah klorofil $a$ terdapat pada lampiran 5. Hasil uji jarak berganda Duncan terhadap jumlah klorofil $a G$. verrucosa pada setiap perlakuan terdapat pada Tabel 2 .

Parameter kualitas air yang diukur selama penelitian adalah suhu $\left({ }^{\circ} \mathrm{C}\right)$ dan $\mathrm{pH}$. Hasil pengukuran suhu selama penelitian berkisar antara $28-32{ }^{\circ} \mathrm{C}$ sedangkan $\mathrm{pH}$ pada saat pemeliharaan berkisar antara 6-8. Hasil pengukuran rata-rata kualitas air dapat dilihat pada Tabel 3 . 
Tabel 2. Hasil uji jarak berganda Duncan terhadap jumlah klorofil a G. verrucosa

\begin{tabular}{|c|c|c|}
\hline Perlakuan & $\begin{array}{c}\text { Jumlah klorofil } a \text { rata-rata } \\
\text { akhir penelitian }(\mu \mathrm{g} / \mathrm{ml})\end{array}$ & $\begin{array}{c}\text { Jumlah klorofil } a \text { rata-rata } \\
\text { (transformasi } \sqrt{ } \mathrm{Y})\end{array}$ \\
\hline A (Kontrol, 24 jam penyinaran) & 0,004838 & $0,05052^{\mathrm{c}}$ \\
B (Lama penyinaran 12 jam terang : 12 jam gelap) & 0,0044002 & $0,06914^{\mathrm{b}}$ \\
C (Lama penyinaran 8 jam terang : 16 jam gelap) & 0,002713 & $0,06576^{\mathrm{b}}$ \\
D (Lama penyinaran 16 jam terang : 8 jam gelap) & 0,006774 & $0,08192^{\mathrm{a}}$ \\
\hline
\end{tabular}

Keterangan : Superskrip yang berbeda menujukkan perbedaan $(\mathrm{p}<0,05)$

Tabel 3. Data rata-rata kualitas air pemeliharaan G. verrucosa

\begin{tabular}{|c|c|c|c|}
\hline Perlakuan & Suhu $\left({ }^{\circ} \mathrm{C}\right)$ & $\mathrm{pH}$ & Salinitas $\left({ }^{\circ}{ }_{\mathrm{oo}}\right)$ \\
\hline A (Kontrol) & 29,17 & 6,8 & 30 \\
B (Lama penyinaran 12 jam terang : 12 jam gelap) & 31,33 & 7 & 30 \\
C (Lama penyinaran 8 jam terang : 16 jam gelap) & 31 & 7 & 30 \\
D (Lama penyinaran 16 jam terang : 8 jam gelap) & 31 & 7,2 & 30 \\
\hline
\end{tabular}

Pertumbuhan rumput laut dipengaruhi oleh beberapa faktor internal dan eksternal. Kamla (2006) menyatakan bahwa faktor internal yang berpengaruh antara lain jenis rumput laut, bagian tubuh (thalus) dan umur rumput laut, sedangkan faktor eksternal yang berpengaruh antara lain keadaan fisika dan kimia perairan. Bird et al. (1997) dalam Ilknur and Cirik (2004) menyatakan bahwa faktor fisika dan kimia perairan yang berpengaruh antara lain gerakan air, suhu, salinitas, nutrien dan cahaya.

Cahaya mempunyai peranan yang sangat penting terhadap proses fotosintesis yang mempengaruhi intensitas dan panjang gelombang (Sudiaji, 2005). Sumber cahaya pada kultur ini menggunakan lampu fluorescent (FL), hal ini disebabkan karena lampu fluorescent menghasilkan cahaya berwarna putih, selain itu sinar lampu fluorescent tidak meningkatkan suhu ruang kultur secara drastis (suhu stabil), dan menghasilkan intensitas cahaya dalam ruang kultur yang sesuai untuk pertumbuhan tunas $G$. verrucosa. Pada penelitian ini cahaya yang digunakan sebesar 3000 lux (Lawlor, 1985).
G. verrucosa sangat memerlukan adanya pencahayaan guna proses fotosintesis yang nantinya akan sangat berpengaruh terhadap pertumbuhannya. Lama penyinaran terbaik terhadap laju pertumbuhan berat $G$. verrucosa pada penelitian ini terdapat pada perlakuan D (lama penyinaran 16 jam terang : 8 jam gelap). Reaksi fotosintesis terdiri dari dua tahap, yaitu reaksi terang dan reaksi gelap (siklus Calvin). Reaksi terang terjadi pada grana (granum), sedangkan reaksi gelap (siklus Calvin) terjadi di dalam kloroplas yang disebut stroma (Lawlor, 1985). Dalam reaksi terang, terjadi konversi energi cahaya menjadi energi kimia dan menghasilkan oksigen $\left(\mathrm{O}_{2}\right)$. Sedangkan dalam reaksi gelap atau yang lebih dikenal dengan siklus Calvin terjadi pembentukan gula dari bahan dasar $\mathrm{CO}_{2}$ yang diperoleh dari udara bebas dan energi (ATP dan NADPH) yang diperoleh dari reaksi terang. Dari reaksi gelap ini, dihasilkan glukosa $\left(\mathrm{C}_{6} \mathrm{H}_{12} \mathrm{O}_{6}\right)$, yang sangat diperlukan bagi reaksi katabolisme. Reaksi katabolisme adalah serangkaian reaksi yang merupakan proses pemecahan senyawa kompleks menjadi senyawa-senyawa yang lebih sederhana dengan membebaskan energi, yang dapat digunakan organisme untuk melakukan aktivitasnya. Fungsi 
reaksi katabolisme adalah untuk menyediakan energi dan komponen yang dibutuhkan oleh reaksi anabolisme (fotosintesis).

Pada perlakuan D (lama penyinaran 16 jam terang : 8 jam gelap) laju pertumbuhan berat $G$. verrucosa sebesar $0,62 \%$ yang tidak berbeda nyata ( $>0,05$ ) dengan perlakuan B (lama penyinaran 12 jam terang : 12 jam gelap) dengan laju pertumbuhan berat sebesar $0,57 \%$ (tabel 3), karena keduanya terdapat reaksi gelap dan terang yang penting sekali untuk metabolisme. Reaksi terang berfungsi untuk mengumpulkan energi kimia dari sinar matahari sehingga pada penyinaran 16 jam terkumpul energi kimia yang lebih banyak untuk digunakan pada reaksi gelap. Apabila reaksi gelap (siklus calvin) tidak berlangsung sama sekali di dalam proses fotosintesis, maka pertumbuhan tanaman tidak berlangsung dengan baik, karena tidak adanya senyawa kompleks dan energi yang bermanfaat untuk memacu pertumbuhan suatu tanaman. Seperti terlihat pada perlakuan A, penyinaran selama 24 jam yang menghasilkan pertumbuhan terendah

Pertumbuhan rumput laut $G$. verrucosa menunjukkan adanya kenaikan pertumbuhan dari minggu ke-0 hingga minggu ke-5 pada setiap perlakuan. Nybakken (1998) berpendapat bahwa pertumbuhan fase vegetatif dari suatu tanaman berhubungan dengan tiga proses penting yaitu proses pembelahan sel yang terjadi pada pembuatan sel-sel baru, proses perpanjangan sel terjadi pada pembesaran sel-sel baru dan proses diferensiasi sel atau pembentukkan jaringan yang terjadi pada perkembangan jaringan-jaringan primer.

Salah satu faktor yang mempengaruhi pertumbuhan rumput laut adalah nutrien yang dapat diperoleh dari pupuk (Aslan, 1998). Pupuk yang digunakan dalam penelitian ini adalah kombinasi antara pupuk TSP dan pupuk NPK dengan perbandingan pupuk TSP dan NPK sebesar $1 \mathrm{gr} / 1$ : 1gr/l. Penggunaan pupuk disini bertujuan untuk meningkakan jumlah unsur hara (makro dan mikro). Penambahan unsur hara dapat menunjang pertumbuhan rumput laut (Susanto, 2001). Dalam penelitian ini semua perlakuan di beri pupuk yang sama sehingga pupuk bukan menjadi variabel yang menyebabkan pertumbuhan berbeda. Keuntungan penggunaan pupuk majemuk seperti pupuk NPK dan TSP adalah kandungan unsur hara nya seimbang dan penggunaan dan pemilihan waktunya sangat efisien, sehingga dapat meningkatkan pertumbuhan tanaman (Peni dkk., 2006).
Selain cahaya dan unsur hara, pertumbuhan rumput laut $G$. verrucosa ini dipengaruhi oleh jumlah klorofil (Platt, 1981). Seperti yang telah diketahui bahwa klorofil adalah zat pembawa hijau daun pada tumbuhan (Carter, 1996). Devlin (1975) dalam Rosana dan Wahopid (2005) menyatakan bahwa klorofil terdiri dalam bentuk klorofil $a, b, c, d$ dan $e$, tetapi dalam alga laut yang dapat diisolasi hanya klorofil $a, b$ dan $c$. Klorofil $a$ terdapat pada semua jenis alga, sedangkan pada klorofil $b$ dan $c$ hanya pada golongan tertentu. Strickland (1960) dalam Rosana dan Wahopid (2005) menyatakan diantara ketiga macam klorofil tersebut, klorofil a merupakan salah satu bagian terpenting dalam proses fotosintesis dan dimiliki oleh sebagian besar alga yang hidup di laut. Jumlah klorofil $a$ juga lebih dominan dibandingkan klorofil $b$ dan $c$. Hal itu juga yang menyebabkan jumlah klorofil $a$ lebih berpengaruh terhadap proses pertumbuhan $G$. verrucosa dibandingkan dengan jumlah klorofil $b$ dan c.

Kloroplast yang ada di dalam klorofil mengandung beberapa pigmen. Klorofil $a$ menyerap cahaya biru-violet dan merah. Klorofil $b$ menyerap cahaya biru dan oranye dan memantulkan cahaya kuning-hijau. Mackinney (1941) menyatakan bahwa klorofil $a$ berperan langsung dalam reaksi terang, sedangkan klorofil $b$ tidak secara langsung berperan dalam reaksi terang. Pada alga hijau kecepatan fotosintesis tinggi pada sinar merah, fotosintesis sedang pada sinar biru dan fotosintesis rendah pada sinar hijau. Di laut cenderung menggunakan sinar sinar dengan spektrum hijau dan biru, karena spektrum merah lebih banyak diserap air (Romimohtarto, 2007).

Komponen utama penyusun klorofil adalah $\mathrm{N}$ dan $\mathrm{Mg}$ (Lawlor, 1993). N diperlukan sebagai bahan dasar penyusun protein dan pembentukkan klorofil dalam fotosintesis. Semakin banyak pembentukkan klorofil maka proses fotosintesis semakin optimal (Jadid, 2008). Mg berperan dalam penangkapan cahaya dalam proses fotosintesis (Lawlor, 1993). Faktor lain yang juga dibutuhkan untuk pembentukan klorofil $a$ adalah nutrien. Aslan (1998) menyatakan bahwa pertumbuhan dan perkembangan rumput laut membutuhkan kualitas cahaya serta nutrien yang cukup seperti nitrat dan fosfat. Nitrat dan fosfat diperlukan sebagai bahan dasar penyusun protein dan pembentukan klorofil dalam proses fotosintesis. Nitrat dan fosfat dapat berasal dari pupuk. Lama penyinaran yang menghasilkan jumlah klorofil a terbaik pada perlakuan D (lama penyinaran 16 jam terang : 8 jam gelap) yang berbeda nyata $(\mathrm{p}<0,05)$ terhadap perlakuan B (lama penyinaran 12 jam terang : 12 jam gelap). Hal ini disebabkan karena 
pada perlakuan D (lama penyinaran 16 jam terang : 8 jam gelap) dihasilkan energi dan karbohidrat yang banyak karena tercukupinya kebutuhan cahayanya. Cahaya yang cukup ini dapat mempengaruhi jumlah klorofil a yang dihasilkan. Sedangkan lama penyinaran yang menghasilkan jumlah klorofil $a$ terendah adalah pada perlakuan A (kontrol, 24 jam penyinaran) yang berbeda nyata $(\mathrm{p}<0,05)$ dengan perlakuan $\mathrm{C}$ (lama penyinaran 8 jam terang : 16 jam gelap). Rumput laut yang diterangi secara terus menerus selama 24 jam tidak terdapat reaksi gelap dimana terjadi proses pembentukan karbohidrat yang penting untuk reaksi katabolisme (pembentukan klorofil) pertumbuhan. Hal ini menyebabkan jumlah klorofil $a$ yang dihasilkan juga akan menurun.

Suhu merupakan salah satu faktor yang penting bagi pertumbuhan rumput laut (Raikar et al., 2001). Hal ini disebabkan oleh suhu mempengaruhi aktivitas metabolisme dan perkembangan suatu organisme (Sahabuddin dan Tangko, 2008). Hasil pengukuran suhu selama penelitian berkisar antara 28$32^{\circ} \mathrm{C}$. Aslan (1998) menyatakan bahwa suhu yang baik untuk pertumbuhan rumput laut berkisar antara 26$33^{\circ} \mathrm{C}$. Raikar et al. (2001) menyatakan bahwa suhu dibawah $25^{\circ} \mathrm{C}$ dapat menyebabkan penurunan pertumbuhan pada Gracilaria sp.

Salinitas merupakan salah satu parameter kualitas air yang cukup berpengaruh pada organisme dan tumbuhan yang hidup di perairan laut (Samsuari, 2006). Luning (1990) menyatakan bahwa salinitas akan menyebabkan adanya turgor antara bagian dalam dan luar rumput laut. Salinitas yang baik untuk pertumbuhan rumput laut $G$. verrucosa berkisar antara $23-30 \%$ dan yang optimum adalah berkisar antara 27 $-30 \%$ (Chen, 1994), sedangkan salinitas pada saat pemeliharaan rumput laut $G$. verrucosa pada kultur pemeliharaan sebesar $30 \%$. Syafruddin (1993) dalam Latif (2008) menyatakan bahwa penurunan dan peningkatan salinitas di atas batas optimum tidak menyebabkan kematian, tetapi mengakibatkan rumput laut kurang elastis, mudah patah dan pertumbuhan akan terhambat.

pH merupakan salah satu faktor penting dalam kehidupan alga laut, sama halnya dengan faktorfaktor lainnya (Samsuari, 2006). pH adalah suatu ukuran dari konsentrasi ion hidrogen dan menunjukan sifat asam atau basa suatu perairan (Summerfelt, 1997). Aslan (2003) menyatakan bahwa kisaran $\mathrm{pH}$ maksimal untuk kehidupan rumput laut adalah 6 - 9 dengan kisaran optimum 6,8 - 8,2, sedangkan $\mathrm{pH}$ air selama pemeliharaan rumput laut G.verrucosa berkisar antara 6-8.
Berdasarkan hal diatas, dapat disimpulkan bahwa kualitas air pemeliharaan $G$. verrucosa selama penelitian yang mencakup suhu, salinitas dan $\mathrm{pH}$ air selama pemeliharaan $G$. verrucosa masih layak dan sesuai dengan kebutuhan hidup G. verrucosa.

\section{Kesimpulan}

Lama penyinaran yang berbeda pada budidaya rumput laut $G$. verrucosa berpengaruh nyata $(\mathrm{p}<0,05)$ terhadap laju pertumbuhan berat $G$. verrucosa.

Lama penyinaran 16 jam terang dan 8 jam gelap memberikan pertumbuhan harian terbaik sebesar $0,62 \% /$ hari. Lama penyinaran yang berbeda pada budidaya rumput laut $G$. verrucosa berpengaruh terhadap jumlah klorofil a G. verrucosa. Lama penyinaran 16 jam terang dan 8 jam gelap memberikan jumlah klorofil terbaik sebesar $0,0068 \mu \mathrm{g} / \mathrm{ml}$.

Pada budidaya rumput laut, untuk meningkatkan laju pertumbuhan harian dan jumlah klorofil $a$ G. verrucosa digunakan lama penyinaran 16 jam terang dan 8 jam gelap.

\section{Daftar Pustaka}

Admin. 2009. The Meaning of Photosynthesis on MIPA for shared. http://wrdbiology. wordpress.com/2009/02/11. 4 hal.

Alamsjah, M. A., F. Ishibashi, H. Kitamura and Y. Fujita. 2006. The Effectiveness of Ulfa fasciata and $U$. pertusa (Ulvales, Chlorophyta) as Algicidal Substances on Harmful Algal Bloom Species. Japan. p. 326.

Anam, M. S. 2007. Petunjuk Budidaya Polikultur Rumput Laut, Bandeng dan Udang di Tambak. Ketahanan Pangan dan Penyuluhan Pertanian. Pasuruan. hal. 9-10.

Andriani, D. 2007. Pengolahan Rumput Laut (Eucheuma cottonii) Menjadi Tepung ATC (Alkali Treated Carrageenophyte) dengan Jenis dan Konsentrasi Larutan Alkali yang Berbeda. http://www.unhas.ac.id. 12/8/2008. 11 hal.

Anggadireja, J. T., A. Zatnika., H. Purwoto., S. Istini. 2006. Rumput Laut. Penebar Swadaya. Jakarta. hal. 40-47.

Aslan, L. M. 1998. Rumput Laut. Kanisius. Jakarta. hal. 13-37.

Atmadja, W. S., A. Kadi., Sulistjo. dan Rachmaniar. 1996. Pengenalan Jenis-Jenis Rumput Laut di Indonesia. Puslitbang Oseanologi LIPI. Jakarta. hal. $120-152$. 
Atmadja, W. S. 1996. Pengenalan Jenis Algae Merah di dalam Pengenalan Jenis-Jenis Rumput Laut Indonesia. www.rumputlaut.org. 30/05/2009. 7 hal.

Atmadja, W. S., 2007. Apa Rumput Laut Sebenarnya. Kelompok Studi Rumput Laut UNDIP. http://www.coremap.org. 10/07/2008. 8 hal.

Carter, S. J. 1996. Photosynthesis. http://www.biology.clc.c. 15/7/2008. 4 pp.

Chen, J. X. 1994. Gracilaria Culture in China. http://www.fao.org. 12/6/2008. 7 pp.

Ekayanti, A. 2004. Pengaruh Pemberian Pupuk NPK Berbeda Terhadap Laju Pertumbuhan Chorella vulgaris. Prodi Bilogi MIPA Intitut Teknologi Surabaya. hal. 10-15.

Eidmen, H. M. 1991. Studi Efektifitas Bibit Algae Laut (Rumput Laut) Salah Satu Upaya Peningkatan Produksi Budidaya Algae Laut (Eucheuma sp). http://www.ipb.ac.id. 24/06.2009. hal. 3.

Hendiarti, N., A. Darmawan., M. Frederik., R. Andiastuti. 2005. Pengukuran Karakteristik Biologi - Kimia Perairan Pulau Nipah Dengan Data Satelit Inderaja dan Pengukuran In-Situ. http://www.oc.its.ac.id. 10/07/2008. 6 hal.

Ilknur, A and S. Cirik. 2004. Distribution of Gracilaria verrucosa (Hudson) Papenfuss (Rhodophyta) in Izmir Bay (Eastern Aegean Sea). Pakistan Journal of Bological Sciences. $7(11):$ 2022-2023.

Jadid, N. 2008. Media kultur Jaringan. http://www.scribd.com. 02/02/2009. 17 hal.

Juneidi, W. A. 2004. Rumput Laut, Jenis dan Morfologi. http://www.smkn 1 nabire.com. 10/07/2008. 56 hal.

Kamla, Y. 2006. Pengembangan Rumput Laut (Eucheuma cottonii) di Kabupaten Kupang $\mathrm{N}$ u s a $\mathrm{T}$ e $\mathrm{n}$ g g a $\mathrm{r}$ a $\mathrm{T}$ i m u r. http://www.damandiri.go.id. 15/7/2008. 12 hal.

Kalkman, I., I. Rajendran and C. L. Angell. 1991. Seaweed (Gracilaria edulis) Farming in Vedalai and Chinnapalam, India. http://www.ftp.fao.org. 1/7/2008.11 pp.

Khasani, I. 2008. Teknologi Corong Tingkatkan Pertumbuhan Dan Kelangsungan Hidup Larva Udang Galah Hingga $95 \%$. http://www.bsn.or.id. 23/09/2008. 2 hal.

Kimball, J. W. 1983. Biologi Edisi Kelima. Institut Pertanian Bogor. Bogor. hal. 173 - 189.
Kusriningrum, R. 1990. Dasar Perencanaan Percobaan dan Rancangan Acak Lengkap. Fakultas Kedokteran Hewan. Universitas Airlangga. Surabaya. hal. 1 - 143.

Latif, I. 2008. Pengaruh Pemberian Pupuk Terhadap Pertumbuhan, Produksi dan Kandungan Karageenan Rumput Laut Kappaphychus striatum.http://www.unhas.ac.id.12/01/2009 4 hal.

Lawlor, D. W. 1993. Photosynthesis. 2nd Edition. Longman Group UK Limited. London. P. 9 23.

Lewmanomont, K. 1995. A Review Paper on The Taxonomy of Gracilaria in Asian Countries. http://www.fao.org. 12/06/2008. 11 p.

Lingga, P. dan Marsono. 2007. Petunjuk Penggunaan Pupuk. Penebar Swadaya. Jakarta. hal. 8 38.

Lobban, C. S., D. J. Chapman and B. P. Kremer. 1988. Spectrophotometric and Fluorometric Chlorophyll Analysis. Cambridge University Press. New York. p. 35-38.

Luning, K. 1990. Seaweeds Their Environment, Biogeography and Ecophisiology. John Wiley \& Sons. New York. p. 328.

Mackinney, G. 1941. Absorption of Light by Chlorophyll Solutions. http://www.jbc.org. 30/07/2008. 8 p.

Mollet, J.C. M.C. Verdus and H. Morvan. 1995. Improved Protoplast Yield and Cell Wall Regeneration in Gracilaria verrucosa (Huds.) Papaenfuss (Gracilaridae, Rhodophyta). France.p. 2-4.

Mukhtar. 2008. Budidaya Rumput Laut. Edisi Revsi. http://www.zeniusmultimedia.com. 9 hal.

Nawawi, G. 2001. Fungsi dan Manfaat Tanah dan Pupuk. Direktorat Pendidikan Menengah Kejuruan. http://www.smk.com. 10/07/2008. 47 hal.

Nybakken, 1998. Biologi Laut (Suatu Pendekatan Ekologis). PT. Gramedia. Jakarta. Hal. 63.

Peni, S. P., T. Mardi dan S. Riyanto. 2008. Pupuk Tunggal vs Pupuk Majemuk. http://www.agrina-online.com. 02/02/2009. 2 hal.

Platt, Trevor. 1981. Physiological Bases of Phytoplankton Ecologyt. Canadian Bulletin of Fisheries and aquatic science. OttawaCanada.

Poncomulyo, T., H. Maryani., L. Kristiani. 2006. Budidaya dan Pengolahan Rumput Laut. Agromedia. Jakarta. hal. 14-15. 
Purwakusuma, W. 2007. Kebutuhan Cahaya. http://www.O-Fish.com. 08/07/2008. 2 hal.

Rahardjo, U. 2003. Klorofil. Purwokerto. http://www.untungsuccess.blogspot.com. 10/08/2008. 2 hal.

Raikar, S. V., M. Iima and Y. Fujita. 2001. Effect of Temperature, Salinity and Light Intensity on The Growth of Gracilaria spp. (Gracilridae, Rhodophyta) from Japan, Malaysia and India. Japan. p. 4.

Rosana, N dan Wahopid. 2005. Pola Distribusi Suhu Permukaan Laut dan Sebaran Klorophil a untuk Menentukan Sebaran Ikan Cakalang (Katsuwonus pelamis) pada Bulan Juli di Jawa Tengah. Jurnal Perikanan, 2 : 14-24 .

Romimohtarto, K. 1985. Kualitas Air Dalam Budidaya Laut. Lampung. http://www.fao.org. 10/08/2008. 5 hal.

Sahabuddin dan A. M. Tangko. 2008. Pengaruh Jarak Lokasi Budidaya Dari Garis Pantai Terhadap Pertumbuhan dan Kandungan Karaginan Rumput Laut Eucheuma cottoni. Seminar Nasional kelautan IV, 24 April 2008. Surabaya. 4 hal.

Sahala, H dan Stewart M. Evans. Pengantar Oseonografi. Penerbit Universitas Indonesia. Jakarta. hal. 54.

Samsuari. 2006. Kajian Ekologis dam Biologi untuk Pengembangan Budidaya Rumput laut (Euchemma cottoni) di Kecamatan Kupang Barat Kabupaten Kupang Propinsi Nusa $\mathrm{T}$ e $\mathrm{n} \mathrm{g} \mathrm{g} \mathrm{a} \mathrm{r} \mathrm{a} \quad \mathrm{T} \mathrm{i} \mathrm{m} \mathrm{u} \mathrm{r.}$ http://www.damandiri.go.id. 15/05/2008. 12 hal.

Sediasdi, A dan U. Budiharjo. 2000. Rumput Laut Komoditas Unggulan. Grasindo. Jakarta.

Silalahi, G.A. 2003. Metodologi Penelitian dan Studi Kasus. Citramedia. Sidoarjo. hal. 1-152.

Subandi, A. 2007 . Metabolisme . http://www.aansma11.blogspot.com. 10/08/2008. 2 hal.
Sudjadi. 2005. Pengaturan Cahaya Lampu Sebagai Fotosintesis Phytoplankton Buatan Dengan Menggunakan MikrokontrolerAt89s52. http://www.emakpancarsakti.com. 01/06/2005. 5 hal.

Sulistjo. 1985. Budidaya Rumput Laut. http://www.elearning.unej.ac.id. 19/05/2009. 7 hal.

Susanto, A. B., Sarjito, A. Djunaedi dan Safuan. 2001. Studi aplikasi Teknik Semprot Dengan Penambahan Nutrien Dalam Budidaya

Rumput Laut Gracilaria verrucosa (Huds) papenf. http://www.pandu.dhs.org. 10/08/2008. 8 hal.

Tra, T. D. 1999. The Culture Gracilaria verruccosa in Tam Giang Lagoon Thua Thien Hue P r o vi n c e S.R. Vi e t n a m . http://www.ftp.fao.org. 01/02/2009. p. $20-$ 24.

Trono, J. C. G. 1998. Present Status of Gracilaria culture. http://www.ftp.fao.org. 02/09/2009. p. $5-12$.

Tubalawony, S. 2008. Kajian Klorofil $a$ Dan Nutrien Serta Interelasinya Dengan Dinamika Mass Air Di Perairan Barat Sumatera Dan Selatan $\mathrm{J}$ a w a $\mathrm{S}$ u m b a w a 20068. http://www.wikipedia.com. 08/07/.2008. 2 hal.

Villares, R., X. Puente and A. Carballeria. 1999. Nitrogen and Phosphorus in Ulva sp in The Galician Rias Bajas (Northwest Spain) : Seasonal Fluctuations and Influence on Growth. http://www.ieo.es. 08/06/2008. 4 pp.

Yuwono, N.W. 2006 . Pupuk Fosfor. http:/www./nasih.staff.ugm.ac.id. 10/07/2008. 2 hal. 